\title{
Links between jellyfish and microbes in a jellyfish dominated fjord
}

\author{
Lasse Riemann $^{1, *}$, Josefin Titelman ${ }^{2}$, Ulf Båmstedt ${ }^{2,3}$ \\ ${ }^{1}$ Department of Natural Sciences, Kalmar University, 39182 Kalmar, Sweden \\ ${ }^{2}$ Department of Biology, University of Bergen, PO Box 7800, 5020 Bergen, Norway \\ ${ }^{3}$ Umeå Marine Science Centre, University of Umeå, Norrbyn, 91020 Hörnefors, Sweden
}

\begin{abstract}
Research on the impact of mass aggregations of jellyfish on foodweb structure has mainly focused on trophic control of copepods and fish larvae, while impacts on lower trophic levels have received little attention. Jellyfish release nutrients and dissolved organic matter through their activities. Hence, both direct and cascading impacts of jellyfish on the bacterial community are conceivable. In the Norwegian Lurefjorden, the abundance of the deepwater scyphomedusa Periphylla periphylla reaches concentrations much higher than in any other area investigated. We used Lurefjorden as a model system to examine effects of high jellyfish biomass on the microbial planktonic foodweb, and targeted bacterial activity and community composition in relation to the distribution of P. periphylla as monitored using a Remotely Operated Vehicle. P. periphylla performed pronounced diel vertical migrations; however, no significant diel effects on microbial activity were observed in surface waters. Surface waters were characterized by a high biomass of mesozooplankton. Integrating over $24 \mathrm{~h}$, the highest jellyfish biomass was found at 200 to $300 \mathrm{~m}$ depth. This concurred with elevated total organic carbon, bacterial production and ectoenzymatic activities. Analysis of bacterioplankton community composition by denaturing gradient gel electrophoresis (DGGE) and 16S rDNA sequencing revealed that specific phylotypes related to Bacteroidetes and to $\delta$-Proteobacteria were found with depth. Overall, phylotypes related to Bacteroidetes dominated the bacterial community. Our results indicate that $P$. periphylla has a structuring impact on the pelagic deep-water microbial community in Lurefjorden. We suggest that jellyfish proliferations may also be quantitatively important for lower trophic levels of the pelagic foodweb.
\end{abstract}

KEY WORDS: Periphylla periphylla $\cdot$ Jellyfish $\cdot$ Bacteria $\cdot$ Community composition $\cdot$ DGGE

\section{INTRODUCTION}

Gelatinous zooplankton occur throughout the water column in all of the world's oceans. When numerous, jellyfish commonly disrupt fisheries, tourism and coastal industries. Whether the frequency and extent of such blooms have increased worldwide remains disputable; however, at local scales numerous examples exist (Mills 2001, Lynam et al. 2004). The ecological impact of jellyfish proliferations on foodweb structure and dynamics may at times be significant. For example, large jellyfish populations may directly control larval fish (Purcell \& Arai 2001) and zooplankton pop- ulations (Olesen 1995). Reports on impact of jellyfish on lower trophic levels are few however, despite the possibility of both indirect cascade effects (Stibor et al. 2004) and direct substrate generation (Hansson \& Norrman 1995). Their voracious feeding activity on zooplankton and fish may potentially elicit cascading effects in pelagic foodwebs affecting trophic levels down to microbes. For instance, Priddle et al. (2003) demonstrated in the northern Scotia Sea that variations in krill biomass change the relative impact of krill and copepods on phytoplankton, which in turn regulates nutrient cycles. Stibor et al. (2004) examined cascading effects on phytoplankton and found that jellyfish con- 
sistently reduced copepod biomass while the net effect on algal biomass depended on initial cell size, and their susceptibility to copepod grazing. Altered phytoplankton size distribution likely influences the release of organic carbon from algal cells (Bjørnsen 1988), which in turn, affects bacterial growth. Jellyfish biomass may also stimulate bacterial growth directly through release of nutrients (Schneider 1989, Nemazie et al. 1993) and bio-available dissolved organic matter (DOM) (Hansson \& Norrman 1995, Titelman et al. 2006, this volume). Hence, by modifying carbon and nutrient conditions jellyfish may potentially influence microbial community composition (Martinez et al. 1996), however this has not yet been examined in situ.

Most jellyfish may undergo rapid population increases, as well as aggregations, in response to changes in food availability and the physical environment. Naturally, the irregularity and unpredictability of these proliferations constrain studies of their impact on the concomitant planktonic community. In a few Norwegian fjords, the perennial deepwater scyphomedusa Periphylla periphylla abounds year-round (Youngbluth \& Båmstedt 2001) forming lasting mass-occurrences with average concentrations of $\sim 0.4 \mathrm{~m}^{-3}$ in the deep basin of Lurefjorden (integrating over the entire water column, Sørnes 2005). Such concentrations are several orders of magnitude greater than in the open ocean (Youngbluth \& Båmstedt 2001).

Here, Lurefjorden was used as a model system to examine the effects of a persistently high jellyfish biomass on the planktonic foodweb and, especially, on bacterial activity and community composition. We hypothesized that the diel vertical migration of jellyfish (Youngbluth \& Båmstedt 2001) would cause an accumulation of jellyfish biomass near the surface at night and at depth during the day, which through the release of bioavailable dissolved organic carbon and nutrients, would stimulate bacterial activity (Schneider 1989, Nemazie et al. 1993, Hansson \& Norrman 1995) near the surface and at depth at day and night, respectively. We also hypothesized that the strong vertical gradient in jellyfish biomass would lead to changes in bacterial community composition with depth.

\section{MATERIALS AND METHODS}

We examined the potential impact of the jellyfish biomass and its tremendous diel biomass-movement on planktonic microbial activity and biomass in the deep basin (max. depth $439 \mathrm{~m}$ ) of Lurefjorden, Western Norway, $\left(60^{\circ} 42.73^{\prime} \mathrm{N}, 05^{\circ} 05.60^{\prime} \mathrm{E}\right)$ on April 22 to 23 , 2004. We conducted a $24 \mathrm{~h}$ study at $5 \mathrm{~m}$ depth, where Periphylla periphylla are completely absent during daytime, but abound at night, as well as a vertical pro- file study to document changes during day and night conditions. The hydrography of Lurefjorden and the biology of $P$. periphylla is described in detail elsewhere (Eiane et al. 1999, Youngbluth \& Båmstedt 2001).

For the $24 \mathrm{~h}$ study, water samples were obtained from $5 \mathrm{~m}$ depth with $10 \mathrm{l}$ Niskin bottles attached to a rosette sampler every $3 \mathrm{~h}$ between 04:00 h April 22 and 04:00 h April 23. The vertical profiles were performed at daytime $(13: 00 \mathrm{~h})$ on April 22 and at nighttime (01:00 h) on April 23, where bottle samples were taken at $5,25,50,100,200$ and $300 \mathrm{~m}$ depth. The water was transferred to $10 \mathrm{l}$ acid-washed containers and sampled for chlorophyll a ( $\mathrm{chl} a$ ), nutrients, total organic carbon (TOC), bacterial production, aminopeptidase and phosphatase activities, bacterial community DNA, and bacterial, viral, ciliate and copepod abundance. Temperature and salinity were measured simultaneously during each sampling. The distribution and biomass of Periphylla periphylla was assessed from video profiles from a Remotely Operated Vehicle (ROV) and net sampling, respectively.

Periphylla periphylla. Methods and equipment associated with sampling $P$. periphylla are described in detail elsewhere (Youngbluth \& Båmstedt 2001, Sørnes $2005)$ and therefore summarized only briefly here. Vertical distribution in the entire water column was assessed from 6 video profiles on April 22-23 by the ROV 'Aglantha' in the deep basin (320 to $439 \mathrm{~m}$ depth). The recordings were conducted at a ROV descent rate of $\sim 0.5 \mathrm{~m} \mathrm{~s}^{-1}$. The depth of each jellyfish was determined, and abundance was subsequently integrated in $10 \mathrm{~m}$ depth intervals. To convert data to concentrations, we multiplied the vertical distance traveled with empirically determined horizontal surface areas of 2.31 and $6.09 \mathrm{~m}^{2}$, determined for small $(2 \mathrm{~cm}$ coronal diameter) and large (10 cm coronal diameter) P. periphylla (Youngbluth \& Båmstedt 2001). Following Sørnes (2005) we report concentrations as ranges using the 2 area factors, as jellyfish sizes cannot be accurately determined with this video set-up. We complimented these data with direct surface counts at night.

Depth integrated Periphylla periphylla biomass was obtained from vertical net tows $(2 \mathrm{~m}$ mouth diameter, $12.5 \mathrm{~m}$ long, 3 to $1 \mathrm{~mm}$ graded mesh size, plastic bag cod end) between the bottom and the surface at a rate of $\sim 6 \mathrm{~m} \mathrm{~min}^{-1}$. The diameter of all animals was measured to the nearest $\mathrm{mm}$ and their wet weight determined to the nearest $0.1 \mathrm{~g}$.

Chl a, nutrients and total organic carbon (TOC). Duplicate 11 samples were filtered and chl a extracted in ethanol and measured using a Turner design 10-AU fluorometer (excitation 340 to $500 \mathrm{~nm}$ band pass; emission $>665 \mathrm{~nm}$ cut-off) calibrated with a standard chl a solution (Sigma). For nitrate/nitrite, ammonia and phosphate, three $12 \mathrm{ml}$ samples were filtered through 
glass fiber filters (Whatman GF/F) into $15 \mathrm{ml}$ polypropylene tubes and frozen until analysis using a Bran \& Luebbe TRAACS 800 autoanalyzer and standard seawater methods (Grasshoff et al. 1983). For TOC, duplicate $12 \mathrm{ml}$ samples were frozen in $15 \mathrm{ml}$ polypropylene tubes and analyzed using a Shimadzu TOC-5000 high temperature catalytic oxidation instrument. Samples were acidified and sparged prior to analysis. Calculation of carbon concentrations was made with potassium hydrogen phthalate as standard substance.

Ciliates. For ciliate counts, $250 \mathrm{ml}$ samples were fixed with Lugol's solution. Ciliates were enumerated under an inverted microscope using sedimentation chambers. Cell volumes $\left(x_{i} \mu \mathrm{m}^{3}\right)$ were estimated from length and width measurements, and converted to carbon biomass $(y ;$ pg C) using the relationship determined for protists: $y=0.216 x^{0.939}$ (Menden-Deuer \& Lessard 2000).

Mesozooplankton. Mesozooplankton from $\sim 51$ were concentrated on a $45 \mu \mathrm{m}$ mesh, preserved in formalin ( $4 \%$ final) and measured and identified under a dissecting microscope. Prosome lengths (copepodids) and total lengths (nauplii) were converted to carbon weights using regressions in Rey-Rassat et al. (2004) (Calanus spp.), Sabatini \& Kiørboe (1994) (Oithona similis, also used for Oncaea spp.), and Berggreen et al. (1988) (Acartia tonsa, used for all other species and for nauplii).

Bacterial and viral abundance. Aliquots of $45 \mathrm{ml}$ were fixed with $0.2 \mu \mathrm{m}$ filtered formalin ( $2 \%$ final) and stored at $4^{\circ} \mathrm{C}$ for $1 \mathrm{mo}$ before bacterial and viral enumeration. Bacteria were stained with SYTO 13 (Molecular Probes) and counted on a FACSCalibur flow cytometer (Becton Dickinson) (Gasol \& del Giorgio 2000) using fluorescent beads (True counts, Becton Dickinson) as standards. For viral counts, 5 to $7 \mathrm{ml}$ aliquots were filtered onto $0.02 \mu \mathrm{m}$ Anodisc filters (Whatman), stained with SYBR Green I (Molecular probes), and mounted in glycerol/p-phenylenediamine (Noble \& Fuhrman 1998). More than 200 viruses filter ${ }^{-1}$ (or $>15$ fields filter ${ }^{-1}$ ) were counted at $1250 \times$ using epifluorescence microscopy (Zeiss Axioplan). Duplicate filters were counted on 3 occasions. The coefficient of variation between duplicate filters was on average $7 \%$. The bacterial and viral counts are probably conservative because of the preservation in formalin (e.g. Wen et al. 2004).

Bacterial production. Bacterial production was measured by $\left[{ }^{3} \mathrm{H}\right]$-thymidine incorporation (Fuhrman \& Azam 1982). For each sample, triplicate aliquots (10 ml) and a fixed blank were incubated with [methyl- $\left.{ }^{3} \mathrm{H}\right]-$ thymidine (10 nM final, Amersham Pharmacia Biotech) in polyethylene vials in a water bath with flowing surface seawater on deck for ca. $1 \mathrm{~h}$. Samples with $5 \%$ trichloroacetic acid added prior to the addition of $\left[{ }^{3} \mathrm{H}\right]-$ thymidine were used as blanks. Samples were filtered onto $0.2 \mu \mathrm{m}$ mixed cellulose ester filters (Advantec MFS), rinsed carefully with ice-cold $5 \%$ trichloroacetic acid, and counted by liquid scintillation spectrometry. Bacterial carbon production was calculated using $1.1 \times$ $10^{18} \mathrm{cells} \mathrm{mol}^{-1}$ thymidine incorporated (Riemann et al. 1987) and a carbon-to-cell ratio of $20 \mathrm{fg} \mathrm{C}$ bacterium $^{-1}$ (Lee \& Fuhrman 1987).

Hydrolytic ectoenzyme activities. Triplicate $4 \mathrm{ml}$ samples were incubated with fluorogenic substrates (methylumbelliferyl [MUF] and amino-methylcoumarin [AMC] derivatives, Sigma) to determine potential hydrolysis rates. The substrates used (and enzymes assayed) were L-leucine-AMC (aminopeptidase) and MUF-phosphate (alkaline phosphatase). Substrate hydrolysis rates were measured with a Turner TD-700 fluorometer using heat-killed samples as controls. The fluorometer was calibrated with standard solutions of MUF and AMC (Sigma) and potential activities at $200 \mu \mathrm{M}$ substrate concentration were measured.

DNA filtration and extraction. For DNA extraction, 2 to 3 liters of water was filtered through a $0.22 \mu \mathrm{m}$ Sterivex capsule filter (Millipore) via a peristaltic pump. Filters were frozen at $-20^{\circ} \mathrm{C}$ until extraction. DNA was extracted from filters using an enzyme/phenol-chloroform protocol as described in Riemann et al. (2000), but with a few modifications: a 30 min lysozyme treatment (5 mg ml${ }^{-1}$, final) and an overnight proteinase $\mathrm{K}\left(2 \mathrm{mg} \mathrm{ml}^{-1}\right.$ final) treatment at $55^{\circ} \mathrm{C}$ as optimized by Boström et al. (2004). DNA was re-suspended in TE (10 mM Tris, 1 mM EDTA, pH 8.0) and quantified fluorometrically (PicoGreen; Molecular Probes).

PCR-amplification, DGGE and 16S rDNA sequencing. Bacterial 16S rDNA was amplified using a Bacterial primer complementary to position 341 to 358 with a 40 bp GC-clamp (Muyzer et al. 1993) and a universal primer complementary to position 907 to 927 (Muyzer et al. 1998). PCR reactions $(75 \mu l)$ contained $1 X$ PCR buffer with $\mathrm{MgCl}_{2}$ (Roche), $0.8 \mathrm{mM}$ deoxynucleotide triphosphates, $0.5 \mu \mathrm{M}$ of each primer, $\approx 7.5 \mathrm{ng}$ of template DNA, and 1.5 units of Taq polymerase (Roche). Initial denaturation was at $95^{\circ} \mathrm{C}$ for 2 min followed by a thermal cycling program as follows: denaturation for $30 \mathrm{~s}$ at $94^{\circ} \mathrm{C}_{\text {; }}$ annealing for $30 \mathrm{~s}$ at an initial $63^{\circ} \mathrm{C}$, decreasing $1^{\circ} \mathrm{C}$ every 2 cycles to a final of $53^{\circ} \mathrm{C}$; extension for $90 \mathrm{~s}$ at $72^{\circ} \mathrm{C}$. Ten cycles were run at $53^{\circ} \mathrm{C}$ for a total of 30 cycles followed by final 7 min incubation at $72^{\circ} \mathrm{C}$. A negative control, in which the template was replaced by an equivalent volume of sterile water, was included in each batch of PCR reactions. Quality and size of PCR products were verified by agarose gel electrophoresis.

Duplicate $75 \mu$ PCR reactions were pooled, purified using the QIAquick Nucleotide Removal Kit (Qiagen), 
and quantified fluorometrically. We analysed $60 \mathrm{ng}$ of PCR product by DGGE using the D Gene System (Bio-Rad) at $60^{\circ} \mathrm{C}$ for $6 \mathrm{~h}$ at $150 \mathrm{~V}$ (Riemann \& Middelboe 2002). DGGE bands were excised, eluted, reamplified, and cloned (Riemann \& Winding 2001). DGGE profiles of re-amplified, cloned DNA were used to check for heteroduplexes and to confirm the position of cloned bands relative to the original sample. Inserts were bi-directionally sequenced using the DYEnamic $^{\mathrm{TM}}$ ET terminator cycle sequencing kit (Amersham Biosciences) and an ABI PRISM 377 sequencer (Applied Biosystems) as described by the manufacturer. Sequences were aligned to known sequences using BLAST (Altschul et al. 1990) and analyzed by the program Chimera Check (Cole et al. 2003). DGGE band sequences have been deposited in GenBank, using the abbreviations LUR 1 to 15 (LUR refers to Lurefjorden), under the accession numbers (in order) AY960276 to AY960290.

\section{RESULTS}

\section{Vertical study}

Basic parameters

The hydrography was characterized by stratification. Temperature decreased rapidly from 7 to $8^{\circ} \mathrm{C}$ near the surface to a minimum of $6^{\circ} \mathrm{C}$ below $100 \mathrm{~m}$. Salinity increased from 31.5 at the surface to 33 below $\sim 30 \mathrm{~m}$.

Visual inspection of Figs. 1, 3 and 4 generally suggested no consistent or systematic differences between day and night profiles. We therefore tested for statistical differences between day and night profiles using paired Wilcoxon Signed-Ranks Tests. For variables where there were no significant differences between day and night, the 2 profiles were pooled before subsequent analyses. With the exception of ammonia ( $p=0.028)$, none of the other basic parameters differed significantly between day and night (all p-values >0.05) (Fig. 1).

Phosphate differed between depths (ANOVA on ranks, $\mathrm{p}<0.001$ ), and generally increased from $0.1 \mu \mathrm{M}$ near the surface to $0.5 \mu \mathrm{M}$ at 200 to $300 \mathrm{~m}$ (Spearman's correlation, $r=0.891, p=0.001$ ). Ammonia did not differ significantly between depths (ANOVA on ranks, $\mathrm{p}=$ 0.255 ) but ranged from $\sim 0.8$ to $0.9 \mu \mathrm{M}$ at 50 to $300 \mathrm{~m}$ to a peak of $\sim 1.2 \mu \mathrm{M}$ at $25 \mathrm{~m}$ (Fig. 1B). Nitrite/nitrate concentrations were variable and differed between depths (ANOVA on ranks, $\mathrm{p}=0.032$ ), increasing from $\sim 0.5 \mu \mathrm{M}$ near the surface to $\sim 4.5 \mu \mathrm{M}$ at $300 \mathrm{~m}$ (data not shown) (Spearman's correlation, $\mathrm{r}=0.887, \mathrm{p}<0.001$ ).

Phytoplankton biomass, proxied by chl $a$, differed between depths (ANOVA on ranks, $p<0.001$ ) decreasing from $\sim 1.5 \mathrm{\mu g} \mathrm{l}^{-1}$ near the surface to $<0.2 \mathrm{\mu g} \mathrm{l}^{-1}$

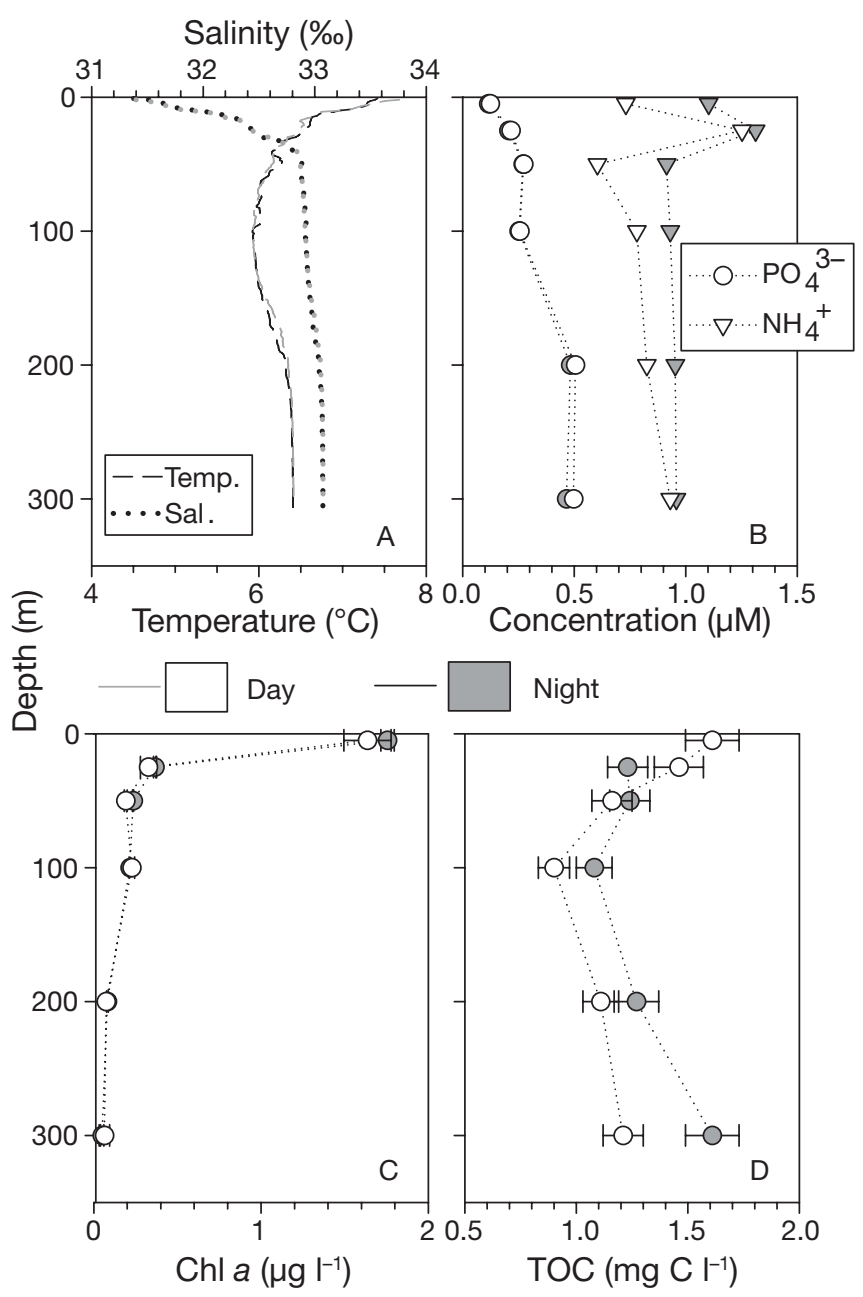

Fig. 1. Vertical distribution of (A) temperature and salinity, (B) nutrients, (C) chl a, and (D) total organic carbon (TOC), for day and night. Error bars are \pm SD based on duplicate samples for (C) chl $a$, and an $8 \%$ error averaged from 10 samples measured in duplicates for (D) TOC

below $50 \mathrm{~m}$ (Fig. 1C) (Spearman's correlation, $\mathrm{r}=$ $-0.961, \mathrm{p}<0.001$ ). Except for a few dinoflagellates, the phytoplankton community consisted almost exclusively of cryptophytes (Plagioselmis spp., C. Legrand pers. comm.) with a maximum concentration of 3800 cells $\mathrm{ml}^{-1}$ at $5 \mathrm{~m}$ (not shown).

Total organic carbon (TOC) was highest near the surface $\left(\sim 2 \mathrm{mg} \mathrm{Cl}^{-1}\right)$, lowest $\left(\sim 1 \mathrm{mg} \mathrm{Cl}^{-1}\right)$ at $100 \mathrm{~m}$, and then increased to $\sim 1.4 \mathrm{mg} \mathrm{Cl}^{-1}$ at $300 \mathrm{~m}$ (Fig. 1D). The fit of a quadratic polynomial to the plotted data statistically confirmed this visual impression of a mid depth minimum; the quadratic term was significant $(p=0.013)$ yielding a TOC minimum at $\sim 151 \mathrm{~m}$ (fit in Fig. 2D). Similarly, TOC concentrations and depth were negatively correlated from 5 to $100 \mathrm{~m}$ (Spearman's correlation, $\mathrm{r}=-0.899, \mathrm{p}=$ 0.003 ) and positively correlated from 100 to $300 \mathrm{~m}$ depth $(\mathrm{r}=0.786, \mathrm{p}=0.032)$. 

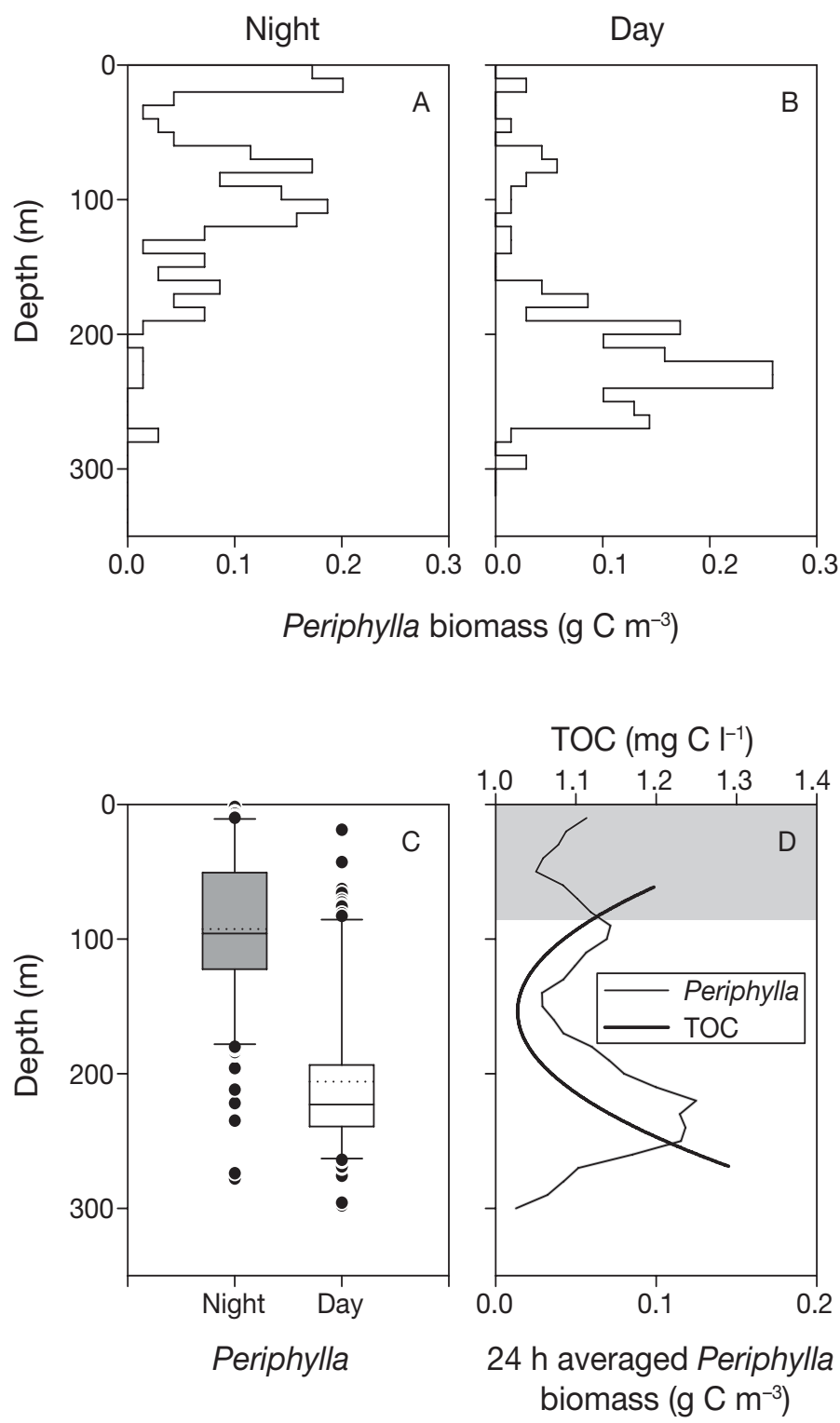

Fig. 2. Periphylla periphylla. Vertical distribution during night and day. (A \& B) Biomass during night and day determined from ROV dives at (A) 21:55 to 22:27 h and (B) 10:31 to $10: 58 \mathrm{~h}$. Data were pooled in $10 \mathrm{~m}$ intervals. Counts were converted to concentrations by using the mean obtained from applying the 2 conversion factors (see 'Materials and methods'). Biomass was then calculated using a mean $P$. periphylla wet weight of $84.3 \mathrm{~g}$ (Table 1) and a conversion factor of $0.571 \pm 0.194 \%$ carbon per unit wet weight (mean $\pm \mathrm{SD}, \mathrm{n}=55$, Båmstedt et al. unpubl.). (C) Box plots of individual depth distribution of $P$. periphylla. Boxes represent the 25th and 75th percentiles, whiskers the 5th and 95th percentiles. The median is indicated by the solid line, the mean by the stippled line, and outliers as circles. (D) $24 \mathrm{~h}$ integrated biomass of $P$. periphylla calculated from (A) \& (B) by weighting with hours of daylight. Data are smoothed with a running average of 5 depth intervals. The line for TOC is the fit of a quadratic polynomial to the data in Fig. 1D. The fit is only shown for the depths where P. periphylla and TOC are correlated (see 'Results'). Grey shading indicates zone influenced by phyto- and zooplankton
Biomass and distribution of Periphylla periphylla

The continuous profiles of Periphylla periphylla (Fig. 2) allowed for comparison of the depth distribution by day and night using a 2-sample KolmogorovSmirnov test. Day and night distributions differed significantly ( $\mathrm{p}<0.00001)$. $P$. periphylla performed a pronounced diel vertical migration from a mean depth of $92 \pm 61 \mathrm{~m}$ at night to $206 \pm 58 \mathrm{~m}$ during the day (mean $\pm \mathrm{SD}$ ) (Fig. 2C). Estimated biomass near the surface was $0.2 \mathrm{~g} \mathrm{C} \mathrm{m}^{-3}$ during the night, but 0.2 to $0.3 \mathrm{~g} \mathrm{C} \mathrm{m}^{-3}$ at 200 to $300 \mathrm{~m}$ depth during the day (Fig. 2A,B). As determined from ROV video profiles, the peak concentration was $\sim 3.3 \times$ the average concentrations (Table 1). This pattern was consistent in all profiles (data not shown). At midnight, surface counts of $P$. periphylla from deck revealed up to $0.5 \mathrm{~m}^{-2}$; no $P$. periphylla were observed at the surface during the day.

To compare the video-based depth profiles of Periphylla periphylla distribution with TOC distribution, sampled at discrete depths, average profiles were constructed for both variables. For $P$. periphylla a $24 \mathrm{~h}$ integrated depth profile was made by weighting the day and night depth profiles (Fig. 2A,B) with respect to light (15.25:8.75 h light:dark). This procedure revealed a local minimum of $P$. periphylla at $\sim 130$ to $160 \mathrm{~m}$ (Fig. 2D), which coincided with the TOC minimum (Figs. 1D \& 2D). Mean P. periphylla biomass (g C $\mathrm{C}^{-1}$ ) was subsequently calculated for depth intervals corresponding to the depths of TOC measurements $(0-5$, $5-25,25-50,50-100,100-200$ and $200-300 \mathrm{~m})$. TOC values were first normalized to the highest value in each profile (day and night), where after an average TOC distribution was calculated for the same depth intervals as above. A Spearman's correlation analysis revealed no significant correlations between $P$. periphylla biomass and TOC, when including data for the entire water column pooled in this way $(\mathrm{r}=0.600, \mathrm{p}=$ $0.104, \mathrm{n}=6$ ). However, the TOC concentration in surface waters is influenced by phytoplankton and mesozooplankton activities (Figs. 1, 2D \& 3), and the $24 \mathrm{~h}$ integrated $P$. periphylla profile has 2 distinct peaks (Fig. 2D). It is therefore relevant to compare different sections of the water column separately. Visual inspection of Fig. 2D suggests that $P$. periphylla distribution and TOC are well correlated between $\sim 80 \mathrm{~m}$ and $\sim 260 \mathrm{~m}$, but not at depths influenced by phytoplankton and mesozooplankton, and below the largest $P$. periphylla peak (260 to $300 \mathrm{~m}$ ). This relationship was confirmed by a Spearman's correlation analysis of $20 \mathrm{~m}$ depth interval raw data for both $P$. periphylla and TOC. The TOC subdivisions were constructed by interpolation from the discrete sampling depths (cf. Fig. 1D). TOC and $P$. periphylla concentrations were positively 
Table 1. Periphylla concentration as determined from ROV transects and MIK nets in the deep basin of Lurefjorden, April 20 to 23, 2004. All data are mean $\pm \mathrm{SD}$. Data from ROV profiles are given as a range using the 2 conversion factors (see 'Materials and methods')

\begin{tabular}{|lccc|}
\hline & \multicolumn{2}{c}{$\operatorname{ROV}(\mathrm{n}=6)$} & \multirow{2}{*}{ MIK $(\mathrm{n}=2)$} \\
& $6.09 \mathrm{~m}^{2}$ & $2.31 \mathrm{~m}^{2}$ & \\
\hline $\begin{array}{c}\text { Integrated concentration, } \\
0 \mathrm{~m} \text { to bottom (ind. } \mathrm{m}^{-3} \text { ) }\end{array}$ & $0.077 \pm 0.020$ & $0.202 \pm 0.054$ & $0.053 \pm 0.008$ \\
$\begin{array}{c}\text { Max. concentration at any } \\
\left.10 \mathrm{~m} \text { depth interval (ind. } \mathrm{m}^{-3}\right)\end{array}$ & $0.285 \pm 0.073$ & $0.750 \pm 0.193$ & - \\
$\begin{array}{c}\text { Individual wet weight }(\mathrm{kg}) \\
(\mathrm{n}=122)\end{array}$ & - & - & $0.084 \pm 0.121$ \\
\hline
\end{tabular}

Biomass and distribution of micro- and mesozooplankton

There were no significant differences between day and night profiles for ciliates or copepods (paired Wilcoxon Signed Ranks Tests, all p-values $>0.05)$. Ciliate biomass differed between depths (ANOVA on ranks, $\mathrm{p}=$ 0.001), and was generally negatively correlated with depth decreasing from $\sim 1 \mu \mathrm{g} \mathrm{C} \mathrm{l}^{-1}$ near the surface (Fig. 3A) (Spearman's correlation, $\mathrm{r}=-0.961, \mathrm{p}<$ 0.001). However, ciliates contributed correlated between 80 and $260 \mathrm{~m}(\mathrm{r}=0.667, \mathrm{p}=0.025$, $\mathrm{n}=9$ ). When including depths below the P. periphylla peak (i.e. $>260 \mathrm{~m}$ ) or above $80 \mathrm{~m}$ the correlations break down. insignificantly to total biomass (cf. Figs. 2 \& 3). The mesozooplankton community was dominated by copepods, which were abundant near the surface and at 200 to $300 \mathrm{~m}\left(\sim 10\right.$ copepods $\mathrm{l}^{-1}$, Fig. 3B). The copepod

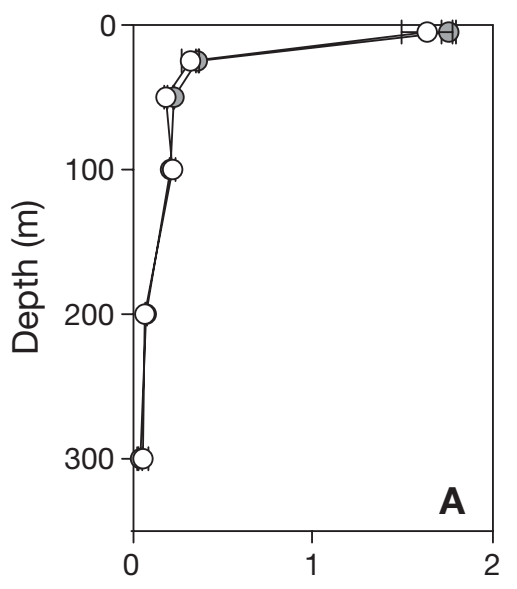

Ciliate biomass $\left(\mu \mathrm{g} \mathrm{C}^{-1}\right)$

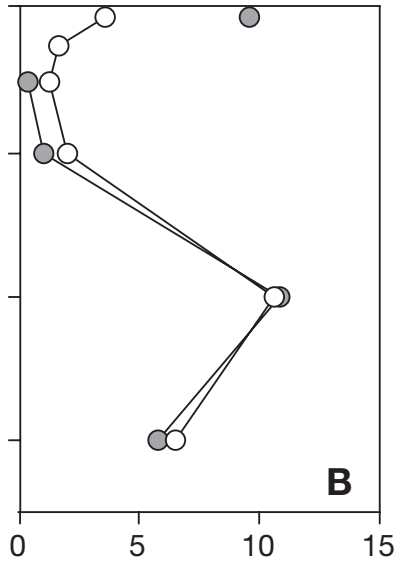

Copepod abundance $\left(I^{-1}\right)$

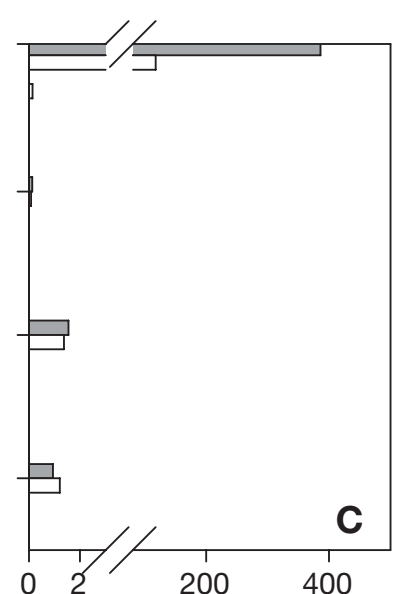

Copepod biomass $\left(\mu \mathrm{g} \mathrm{C}^{-1}\right)$

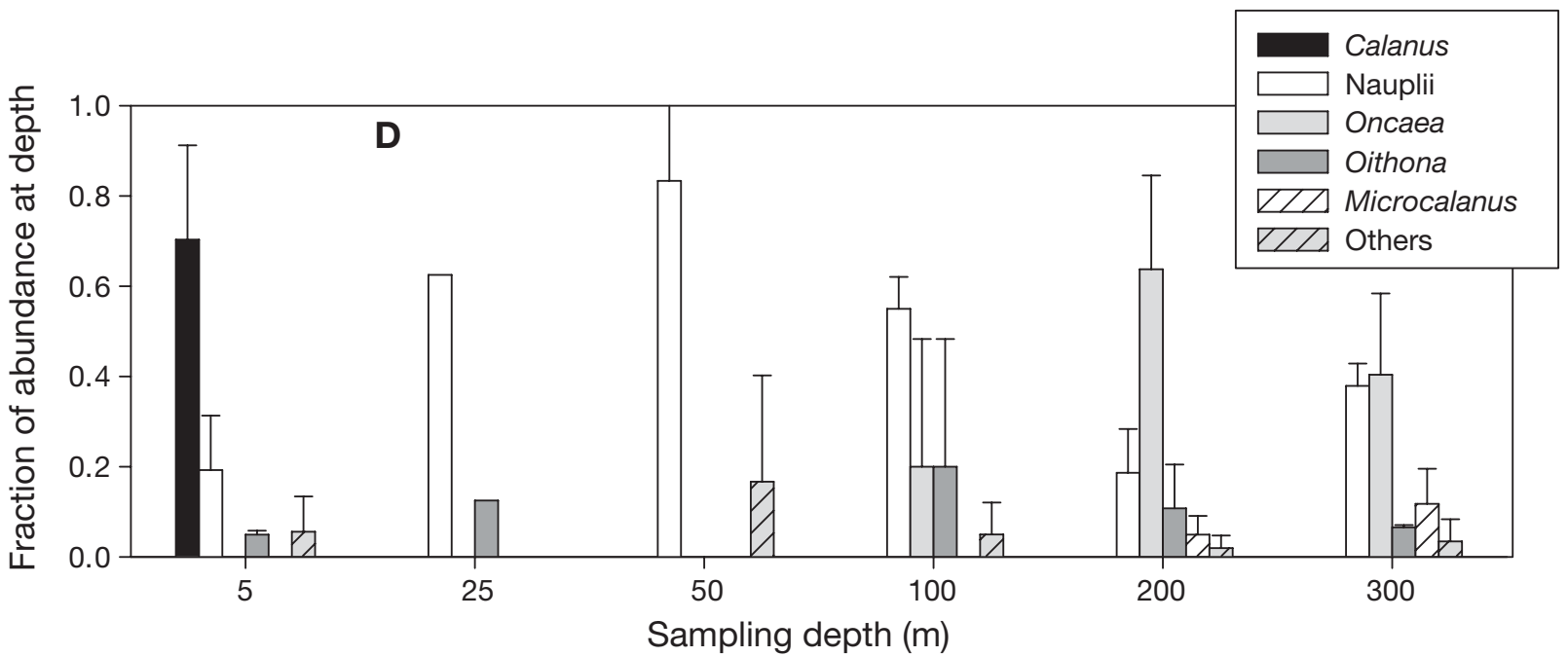

Fig. 3. Vertical profiles of micro- and mesozooplankton during night and day. (A) Ciliate biomass. (B \& C) Copepod abundance and biomass. (A-C) Light and dark symbols indicate day and night samplings, respectively. (D) Taxonomic composition of mesozooplankton as a function of depth. Non-copepod plankton are included in the 'others' category. The composition is calculated as the fraction at depth, such that the total fraction at each depth adds up to 1. Error bars are \pm SD 
community was dominated numerically by Calanus spp. copepodite stages near the surface and by small copepods (mainly Oncaea spp., Oithona spp. and nauplii) at 200 to $300 \mathrm{~m}$ depth (Fig. 3D). Copepod biomass differed between depths (ANOVA on ranks, $\mathrm{p}<0.001$ ). Calanus spp. dominated the copepod biomass, as evident from the $\geq 100$-fold higher values at $5 \mathrm{~m}$ relative to the other depths. The many nauplii and small copepods at depth contributed comparatively little to the biomass (Fig. 3C).

\section{Microbial abundance and activity}

Neither bacterial abundance nor production differed between day and night (paired Wilcoxon Signed Ranks Test, $\mathrm{p}=0.172$ and $\mathrm{p}=0.463$, respectively). Bacterial abundance differed between depths (ANOVA on ranks, $\mathrm{p}=0.001$ ) and generally decreased with depth from $\sim 1.0 \times 10^{6} \mathrm{ml}^{-1}$ near the surface to $\sim 0.2$ to $0.3 \times$ $10^{6} \mathrm{ml}^{-1}$ at 200 to $300 \mathrm{~m}$ depth (Fig. 4A) (Spearman's correlation, $r=-0.961, p<0.001$ ).

Bacterial production was highest near the surface $\left(\sim 2 \mu \mathrm{g} \mathrm{Cl}^{-1} \mathrm{~d}^{-1}\right)$, lowest at 50 to $100 \mathrm{~m}\left(0.1\right.$ to $0.3 \mu \mathrm{g} \mathrm{Cl}^{-1}$ $\left.\mathrm{d}^{-1}\right)$, below which it increased slightly down to $300 \mathrm{~m}$ (Fig. 4B). This visual impression of minimum production at mid-depth was statistically confirmed by a quadratic polynomial fit to the ranked data; the quadratic term (i.e. the minimum) was significant $(p=0.026$ ) (not shown). Similarly, production from 5 to $100 \mathrm{~m}$ was negatively correlated with depth (Spearman's correlation, $r=-0.927, p<0.001$ ), while production between 100 and $300 \mathrm{~m}$ was positively correlated with depth $(\mathrm{r}=$ $0.956, p=0.001$ ). In addition, bacterial production was positively correlated with TOC over the entire water column (Spearman's correlation, $r=0.706, p=0.008$ ).

While aminopeptidase activities did not differ between day and night (paired Wilcoxon Signed Ranks Test, $p=0.463)$, phosphatase activity did $(p=0.028)$. Ectoenzymatic activities apparently mirrored the pattern of bacterial production (Fig. 4) and TOC (Fig. 1) with a minimum at mid-depth. Phosphatase and aminopeptidase activities were highest near the surface $(\sim 10$ and $\sim 50 \mathrm{nM} \mathrm{h}^{-1}$, respectively), lowest between 50 and $100 \mathrm{~m}$ ( 2 and $\sim 20 \mathrm{nM} \mathrm{h}^{-1}$, respectively), and increasing down to $300 \mathrm{~m}$ (Fig. $4 \mathrm{C}, \mathrm{D})$. The quadratic term (i.e. the minimum) of quadratic polynomial fits to the ranked data versus depth was significant for aminopeptidase $(\mathrm{p}=$ 0.004), but not for phosphatase $(p=0.052)$. Separate correlations between enzyme activity and depth, for the depth ranges 5 to $100 \mathrm{~m}$ and 100 to $300 \mathrm{~m}$ also suggested an activity minimum at mid-depth for aminopeptidase (Spearman's correlation, 5 to $100 \mathrm{~m}: \mathrm{r}=$ $-0.976, p<0.001 ; 100$ to $300 \mathrm{~m}: \mathrm{r}=0.956, \mathrm{p}=0.001)$ and phosphatase ( 5 to $50 \mathrm{~m}: \mathrm{r}=-0.849, \mathrm{p}=0.016 ; 50$ to
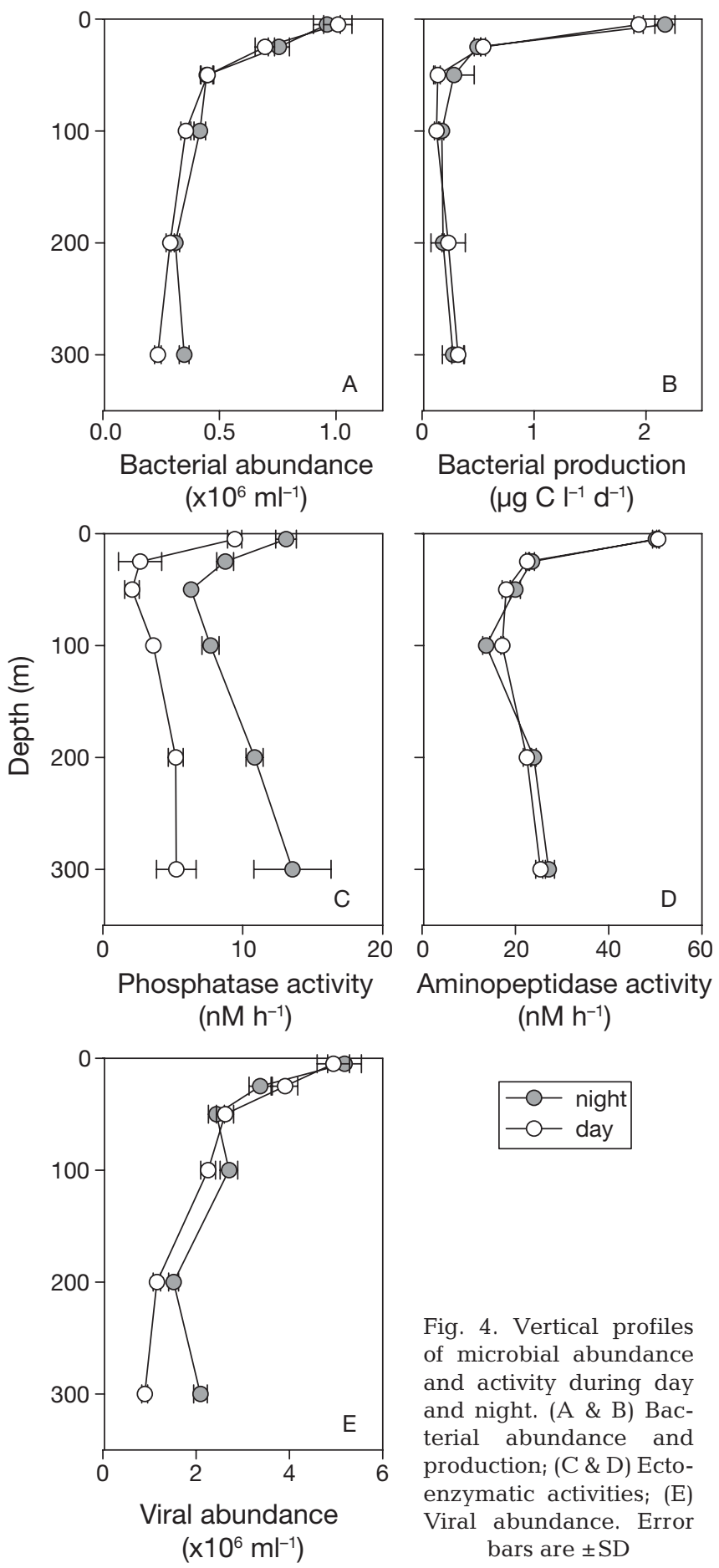

Fig. 4. Vertical profiles of microbial abundance and activity during day and night. (A \& B) Bacterial abundance and production; (C \& D) Ectoenzymatic activities; (E) Viral abundance. Error bars are \pm SD

$300 \mathrm{~m}: \mathrm{r}=0.732, \mathrm{p}=0.019$ ). For phosphatase activity, which differed between day and night, data were normalized against the highest value in its respective profile, before the correlation analysis. The 2 enzyme activities were positively correlated with each other (Spearman's correlation, $r=0.664, p=0.004$ ). Both aminopeptidase and phosphatase activity were also 
positively correlated with TOC over the entire water column (Spearman's correlation, $r=0.806, p=0.001$, and $\mathrm{r}=0.547, \mathrm{p}=0.041$, respectively). However, while bacterial production and aminopeptidase activity were significantly correlated (Spearman's correlation, $\mathrm{r}=$ 0.755, $\mathrm{p}=0.002)$, the correlation was not significant for phosphatase activity $(r=0.455, p=0.074)$.

Viral abundance did not differ between day and night (Wilcoxon's paired rank test, $\mathrm{p}=0.345$ ), but differed between depths (ANOVA on ranks, $p=0.001$ ). Viral abundance was negatively correlated with depth (Spearman, $\mathrm{r}=-0.933, \mathrm{p}<0.001$ ) decreasing from $\sim 5 \times 10^{6} \mathrm{ml}^{-1}$ near the surface to $\sim 1-2 \times 10^{6} \mathrm{ml}^{-1}$ at 200 to $300 \mathrm{~m}$ (Fig. $4 \mathrm{E}$ ). Viral abundance was positively correlated with both bacterial abundance (Spearman, $\mathrm{r}=0.965, \mathrm{p}<0.001$, 1-tailed) and bacterial production (Spearman, $r=0.545$, $p=0.033$ ) over the entire water column.

\section{Bacterial community composition}

We used PCR-DGGE analysis of 16S rDNA to examine bacterial community composition. Ideally, this analysis provides a graphical 'fingerprint' of the bacterial community composition. Potential biases inherent in the DNA extraction and PCR-DGGE protocols are described elsewhere (Wintzingerode et al. 1997, Muyzer et al. 1998).

Only minor differences in the relative brightness of DGGE bands were detected when comparing fingerprints from day and night depth profiles, while no differences in the presence (or absence) of bands were discernible (data not shown). The relative brightness of bands changed with increasing depth, especially at 200 to $300 \mathrm{~m}$ (Fig. 5). The PCR-amplicons consisted of 9 to 23 discernible bands with a marked increase in the number of bands from the surface to deeper samples.

Fifteen different bands from the gel were excised, cloned and sequenced to obtain an impression of bacterial community composition. Bands from different depths with identical vertical positions in the gel had identical sequences (Band 10; Fig. 5). The sequenced amplicons were related to Bacteroidetes $(47 \%)$, photosynthetic organisms $(20 \%), \alpha-(13 \%), \delta$ - $(13 \%)$ and $\gamma$-Proteobacteria (7\%) (Fig. 5, Table 2). Except for 2 amplicons related to Bacteroidetes (Bands 5 and 13), the amplicons were closely related to known sequences in the databases (96.1 to $100 \%$ similarity). No heteroduplexes or chimeras were found among the excised bands.

Seven bands (1 to 5, 9 and 13) were related to clones within the Bacteroidetes phylum from various marine waters (Table 2). Interestingly, 3 of these bands (1, 3 and 9) were observed exclusively at intermediate depths (25 to $100 \mathrm{~m}$ ), while 4 bands $(2,4,5$ and 13) were dominant exclusively in samples from 200 to $300 \mathrm{~m}$

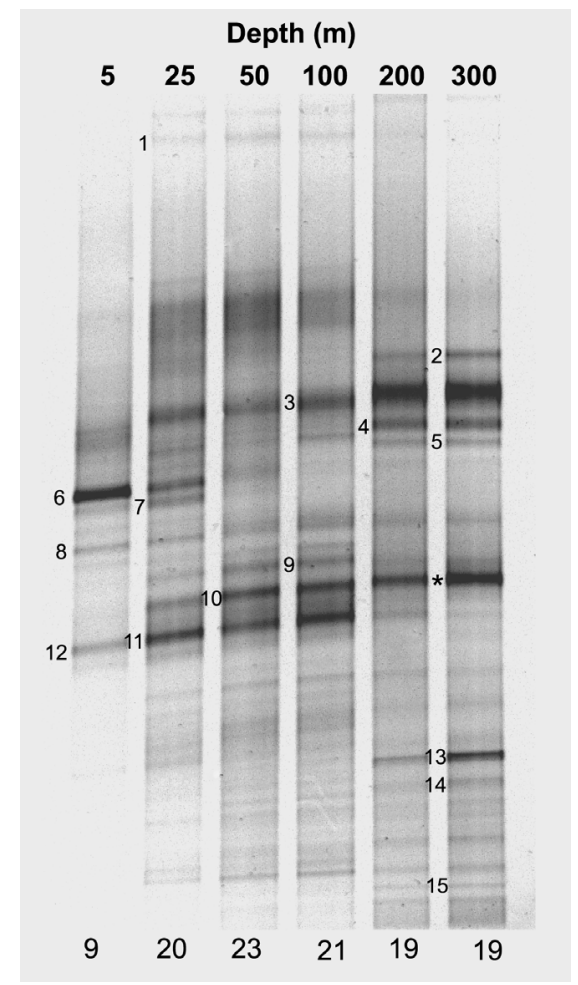

Fig. 5. Bacterial community composition profiles of samples from various depths. A denaturing gradient top to bottom of 29 to $52 \%$ was applied. The total number of discernible bands in each sample is shown below the gel. Excised and sequenced bands are numbered to the left of the lane. *Excised band with the same vertical position as band 10 . The relationships of excised band sequences to other sequences in the GenBank database are shown in Table 2

depth. Bands 2 and 4 showed a high similarity (>97\%) to clones from an estuary (Northeastern Massachusetts, Acinas et al. 2004), while bands 1, 3, 5 and 9 were related to sequences obtained from various marine localities. The nearest relatives of bands 5 and 9 (94.4\% and $96.1 \%$ similarity, respectively) were sequences obtained from the northern part of the North Sea during a coccolithophore bloom (Zubkov et al. 2002) and from the British part of the North Sea. Band 13 was only distantly related $(90.4 \%)$ to a sequence obtained from a diatom culture (Schäfer et al. 2002).

Three bands (6 to 8 ) were related to photosynthetic organisms and were exclusively found down to $25 \mathrm{~m}$ depth. While bands 6 and 7 were almost identical to a cyanobacterial and a eukaryotic clone, respectively, band 8 was identical to a plastid from Dinophysis norvegica (Takishita et al. 2005). This plastid has recently been shown to be a so-called kleptoplastid originating from the cryptophyte Teleaulax amphioxeia (Janson 2004). Both Dinophysis spp. and cryptophytes were observed microscopically in our samples (data not shown). 


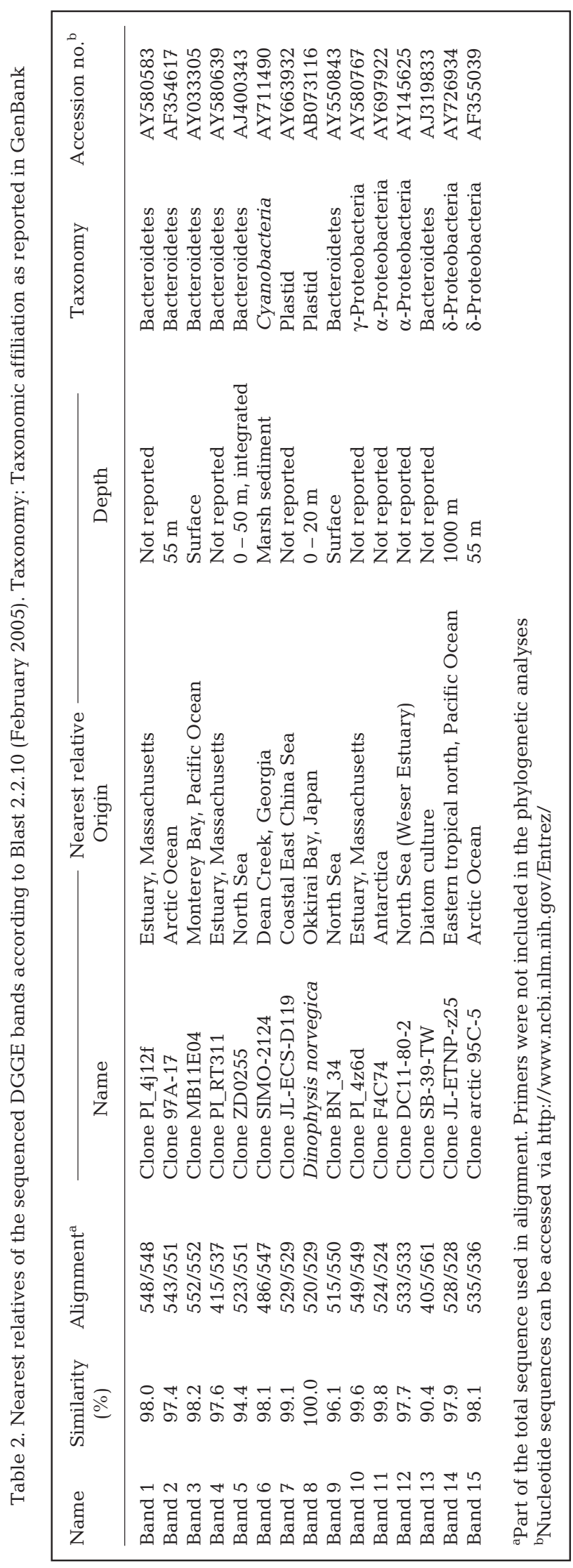

Band 10, which was seen as a bright band at all depths except at the surface, was $>99 \%$ identical to a $\gamma$-Proteobacteria clone from an estuary (Acinas et al. 2004). Bands 11 and 12 were related to sequences affiliated with the Roseobacter clade of $\alpha$-Proteobacteria. Band 11 appeared as a dominant band at 25 to $100 \mathrm{~m}$ depth and was almost identical to a sequence from Antarctica. Band 12, which had almost the same vertical position in the gel as Band 11, was closely related $(97.7 \%)$ to a clone from the German Bight, North Sea (Selje et al. 2004). Both bands were also closely related $(99.6 \%$ and $97.7 \%$, respectively) to sequences obtained from the central North Sea during a coccolithophorid bloom (Gonzalez et al. 2000).

Bands 14 and 15 were found solely at 200 to $300 \mathrm{~m}$ and were closely related to $\delta$-Proteobacteria clones from the Pacific $(1000 \mathrm{~m})$ and Arctic (55 m) Oceans (Bano \& Hollibaugh 2002). These sequences cluster within the so-called Marine Group B/SAR324 clade, which are proportionally most abundant in the aphotic zone of the Atlantic and Pacific Oceans (Fuhrman et al. 1993, Wright et al. 1997) and the North Sea (Gonzalez et al. 2000).

\section{Diurnal study}

We examined whether the vertical migration of Periphylla periphylla from depth to the surface had an immediate effect on microbial activity at $5 \mathrm{~m}$ (Fig. 6). The stability of salinity and temperature at $5 \mathrm{~m}$ depth during the 24 h study (cf. Fig. 1) suggested that vertical mixing was negligible. While $P$. periphylla exhibited a clear diel migration pattern (Figs. 2 \& 6), visual inspection revealed no apparent cyclic patterns over the $24 \mathrm{~h}$ period at $5 \mathrm{~m}$ for any of the other variables (Fig. 6). To quantify possible diel differences, data were grouped into night and day based on hours of light (Fig. 6) and tested for differences with a Mann-Whitney $U$-test. Except for $P$. periphylla, there were no significant differences between day and night in any of the variables (all p-values >0.05).

Bacterial community composition as obtained from sampling at times 07:00, 13:00, 19:00 and 01:00 h was stable. Only minor differences in the relative brightness of bands were detected and no differences in the presence or absence of bands were discernible (data not shown).

\section{DISCUSSION}

Theoretically, direct release of DOC (Hansson \& Norrman 1995) and nutrients (Schneider 1989, Nemazie et al. 1993) from jellyfishes, combined with the 

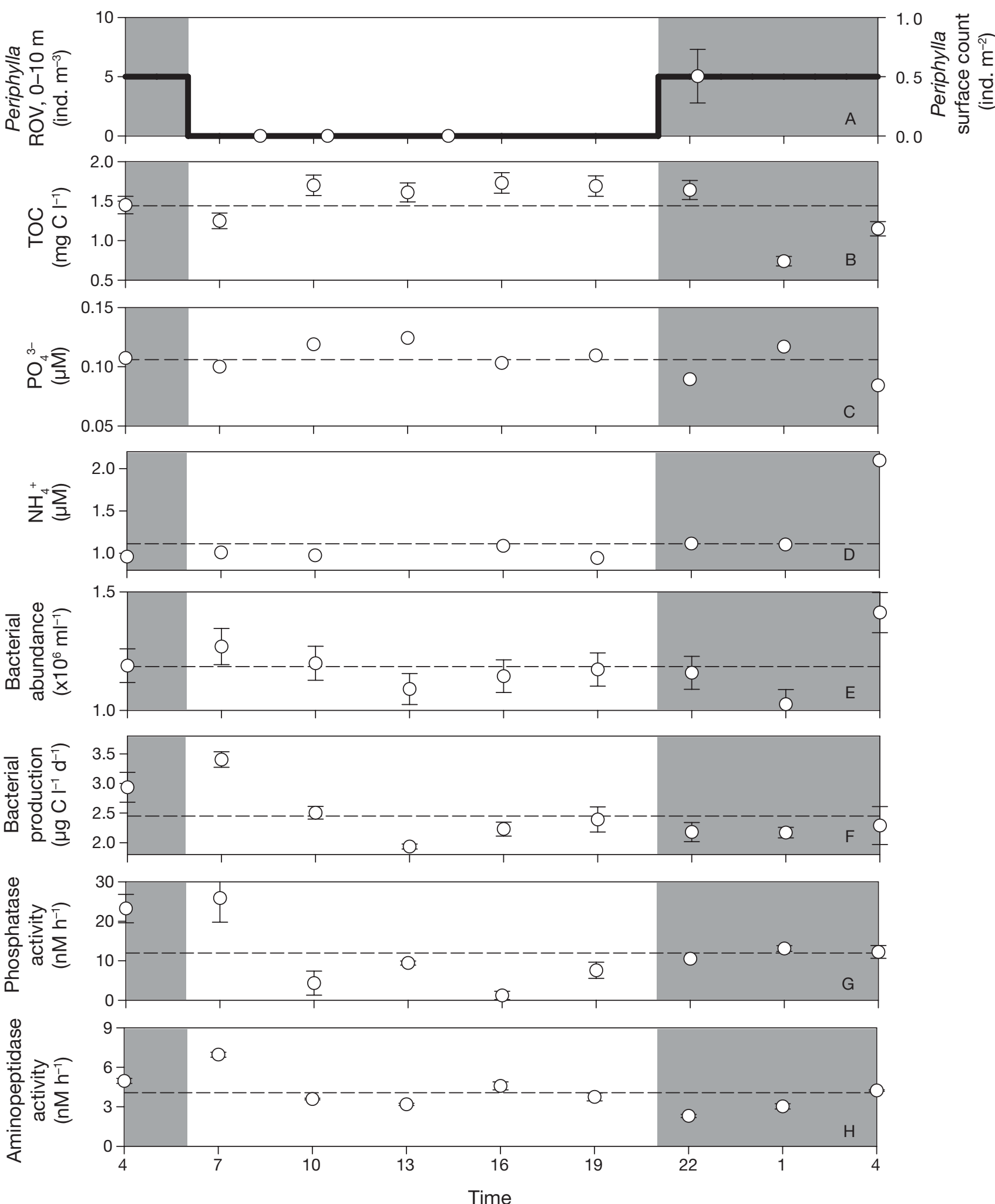

Fig. 6. Periphylla periphylla. Summary of the $24 \mathrm{~h}$ study at $5 \mathrm{~m}$ depth. (A) concentrations (open symbols) between 0 and $10 \mathrm{~m}$ as determined from ROV transects. The symbol indicates the mean concentration, error bars the min and the max, when using the 2 conversion factors (see 'Materials and methods'). Overlaid thick line shows surface counts ( $\mathrm{m}^{-2}$ ). (B) Total organic carbon (TOC) concentrations; (C \& D) nutrients concentrations; (E) bacterial abundance; (F) bacterial production; (G \& H) ectoenzymatic activities. Data are mean \pm SD. Grey shading indicates dark hours, with sunrise at 06:00 h, and sunset at 21:16 h 
re-structuring impact of jellyfish predation on higher trophic levels (Olesen 1995, Purcell \& Arai 2001, Stibor et al. 2004) should affect bacterial growth conditions through changes in substrate quantity and quality. Hence, changes in bacterial community composition would be expected (Martinez et al. 1996). Here, we used Lurefjorden as a model of a jellyfish dominated system to examine effects of a large vertically migrating jellyfish population on microbial abundance, activity and community composition in situ. In an accompanying study, we demonstrated that dead Periphylla periphylla may stimulate as well as inhibit growth of various bacterial species (Titelman et al. 2006).

\section{Coupling between jellyfish, TOC and bacterial activity at depth?}

Given the $>15 \mathrm{~h}$ of daylight at the time of sampling, $>50 \%$ of the Periphylla periphylla biomass was located at 200 to $300 \mathrm{~m}$ depth when integrating over a day (Fig. 2D). Interestingly, the depth of minimum P. periphylla concentrations coincided with the TOC minimum. We attribute the subsurface elevated levels in TOC to the large $P$. periphylla biomass at depth, as we can rule out alternative explanations related to mixing and activities of other biota. Marine subsurface maxima of TOC resulting from a deep mixing event have been observed in the Sargasso Sea (Carlson et al. 1994). For Lurefjorden mixing is an unlikely explanation for the mid-water TOC minimum and elevated TOC levels at depth, as water exchange is restricted primarily to the layer above the sill, while the rest of the water column is vertically stable (sill depth $=20 \mathrm{~m}$; Youngbluth \& Båmstedt 2001, Sørnes 2005). P. periphylla dominates the pelagic biomass in Lurefjorden. The number of jellyfish was recently estimated from 4 yr of surveying to be $0.4 \pm 0.25 P$. periphylla $\mathrm{m}^{-3}$ year round (Sørnes 2005). The biomass of other biota, whose activities could potentially contribute to the TOC pool (e.g. Møller et al. 2003), is generally insignificant in the deeper parts of Lurefjorden (Figs. 1 \& 3; Båmstedt \& Youngbluth 2001, Sørnes 2005).

The combination of only 3 discrete TOC sampling depths, which were not influenced by phytoplankton productivity $(100,200$ and $300 \mathrm{~m})$, and a continuous profiling of Periphylla periphylla with 2 distinct peaks hamper statistical analyses; correlations between $P$. periphylla biomass and TOC are not significant at such large depth intervals (and low n). However, interpolation and subdividing into $20 \mathrm{~m}$ intervals yielded a significant correlation between TOC and P. periphylla between 80 and $260 \mathrm{~m}$, i.e. at depths around and below the minimum TOC (see 'Results'). It is not surprising that TOC and P. periphylla profiles do not correlate perfectly at large depths, as the resolution of the TOC sampling was much lower than that of the P. periphylla sampling; i.e. there are no TOC samples from the $P$. periphylla peak. Also, the amplitude of the $P$. periphylla migration varies with season with deeper distribution in autumn (Sørnes 2005), which may influence the TOC distribution at greater depths.

The pattern of a TOC minimum at 100 to $150 \mathrm{~m}$ with increasing levels towards the bottom was accompanied by quantitatively similar patterns in bacterial production and ectoenzymatic activities. Bacterial activities were higher at 200 to $300 \mathrm{~m}$ relative to those at $100 \mathrm{~m}$ depth. This is in contrast to the North Atlantic, where bacterial production and enzyme activity decrease steadily with depth (0 to $300 \mathrm{~m}$, Hoppe et al. 1993). Here we observed significant correlations between TOC and measures of bacterial activity. Hence, it is tempting to speculate that the elevated bacterial activity with depth in Lurefjorden is due to readily accessible carbon released by the Periphylla periphylla. Hansson \& Norrman (1995) found that the jellyfish Aurelia aurita stimulated bacterial growth by releasing $\sim 1 \mathrm{mg}$ DOC ind. ${ }^{-1} \mathrm{~d}^{-1}$. They speculated that this release may be quantitatively important in semienclosed systems with many jellyfish (Hansson \& Norrman 1995). Physiological differences between $P$. periphylla and A. aurita may bias attempts to calculate the release of DOC from $P$. periphylla, as may the wide size variation in P. periphylla (0.05 to 2000 g, Sørnes 2005). However, directly applying the weight normalized release rate of $A$. aurita $(0.012 \mathrm{mg} \mathrm{C}$ [g wet weight jellyfish $]^{-1} \mathrm{~d}^{-1}$; Hansson \& Norrman 1995), P. periphylla ROV concentrations of $0.75 \mathrm{~m}^{-3}$, and a mean wet weight of $84 \mathrm{~g}$ (Table 1) suggest release rates of $\sim 0.8 \mathrm{mg} \mathrm{C} \mathrm{m}^{-3} \mathrm{~d}^{-1}$ in the layers of high $P$. periphylla abundance. The persistent $P$. periphylla population, in combination with the limited water exchange in Lurefjorden (Sørnes 2005), may thus contribute substantially to the DOC pool at depth on a yearly basis. In an accompanying paper, we found that dead P. periphylla leak TOC at rates as high as $0.5 \mathrm{mg} \mathrm{C}$ ( $\mathrm{g}$ wet weight jellyfish) $)^{-1} \mathrm{~d}^{-1}$ (Titelman et al. 2006).

\section{Bacterial community composition}

To our knowledge, the DGGE and 16S rDNA analyses performed here provide the first information available on bacterial community composition from a marine system consistently dominated by jellyfish. The number of discernible bands was from 9 to 23, which is well within the range usually reported for marine waters (e.g. Fandino et al. 2001, Riemann \& Middelboe 2002). The most striking findings from the analyses were (1) the profound dominance of phylotypes within 
Bacteroidetes, (2) the pronounced differences in composition with depth, and (3) the presence of several phylotypes exclusively at 200 to $300 \mathrm{~m}$ depth.

Of the 15 different sequenced bands, 7 were related to Bacteroidetes clones previously obtained from marine waters. In a recent comparison of fluorescent in situ hybridization and DGGE, Castle \& Kirchman (2004) found that their DGGE approach adequately sampled members of Bacteroidetes. Hence, although only some of the discernible DGGE bands were sequenced, we conclude that a large fraction of the bacterial community in Lurefjorden consisted of members of Bacteroidetes. Members of this phylum are generally among the most abundant marine bacteria (reviewed by Kirchman 2002) and are believed to specialize in particle colonization and degradation (DeLong et al. 1993, Riemann et al. 2000). More recently, findings of Bacteroidetes as important free-living organisms (e.g. Fandino et al. 2001) preferring polymeric substrates (Cottrell \& Kirchman 2000) suggest that they might be specialized in degradation and uptake of high molecular weight DOM (Kirchman 2002). Lurefjorden is characterized by a high light attenuation coefficient, i.e. the light absorbance at $200 \mathrm{~m}$ is 2 to 3 times higher than in nearby fjords (Eiane et al. 1999). The dark environment favors jellyfish over fish, which are generally lacking in Lurefjorden (Eiane et al. 1999, Aksnes et al. 2004). Lurefjorden is less saline than neighboring fjords, and the water is partly of coastal origin (from the Baltic Sea and the rivers entering the North Sea) (Eiane et al. 1999). Members of Bacteroidetes are particularly efficient consumers of riverine DOM (Kisand \& Wikner 2003). Hence, we hypothesize that the dominance of Bacteroidetes in Lurefjorden stems from prevailing substrate conditions governed by a combination of the coastal origin of the basin water and Periphylla periphylla.

Several dominant bacterial phylotypes were found solely in deep water. Four phylotypes (Bands 2, 4, 5 and 13) within Bacteroidetes were only observed in samples from 200 to $300 \mathrm{~m}$ depth. Of these bands, 5 and 13 were only distantly related to sequences in GenBank (94.4 and 90.4\% similarity, respectively) suggesting that they might represent hitherto unknown species. Two other phylotypes (Bands 14 and 15) found at 200 to $300 \mathrm{~m}$ depth were related to the $\delta$-Proteobacteria Marine Group B/SAR324 cluster (Wright et al. 1997). The SAR324 cluster was vertically stratified in the water columns of both the Atlantic and Pacific Oceans with maxima between 160 and $500 \mathrm{~m}$ (Wright et al. 1997). A similar vertical distribution was found in the North Atlantic (Gonzalez et al. 2000). Hence, the 2 phylotypes belong to a phylogenetic group, which may be functionally specialized for life in the deep sea (Wright et al. 1997).
The depth-specific distribution of a significant number of bacterial phylotypes in Lurefjorden may be caused by the distribution of jellyfish through direct or indirect effects on microbial growth and/or mortality. As judged from bacterial abundance and production (Fig. 4), bacterial mortality increased with depth. Presumably, this was not caused by increased viral lysis with depth as virus:bacteria ratios were stable throughout the water column. The abundance of heterotrophic flagellates was low near the surface $\left(<200 \mathrm{ml}^{-1}\right.$, not shown); however, flagellates, taking advantage of the limited grazing pressure from ciliates, could potentially increase in concentration with depth. Flagellate grazing, although sometimes assumed unselective, has the potential to affect bacterial community composition (Šimek et al. 1999). Gel-analyses-based observations of specific bacterial phylotypes associated with deeper waters, e.g. in the Arabian Sea (Riemann et al. 1999) and Antarctic coastal waters (Murray et al. 1998), suggest that environmental conditions associated with increased depth are generally highly selective. Thus, the presence of specific bacterial phylotypes at 200 to $300 \mathrm{~m}$ depth in Lurefjorden may be influenced by other factors than the conspicuous presence of a large biomass of Periphylla periphylla and the associated high levels of TOC.

Two bands were closely related to sequences within a recently defined cluster of the $\alpha$-Proteobacteria Roseobacter clade (Selje et al. 2004). Members of this cluster occur in many marine temperate and polar regions and account for $\sim 10 \%$ of total bacteria in the German Bight, North Sea (Selje et al. 2004 and references therein). The presence of these bacteria in Lurefjorden is not surprising given the water exchange with the North Sea.

\section{Diel effect of jellyfish in surface waters?}

The microbial abundance and activity near the surface did not appear to be altered by a high abundance of Periphylla periphylla. Conceivably, the carbon released from $P$. periphylla was masked by other sources of bioavailable carbon, e.g. phytoplankton and copepod biomass and activity. Near the surface, the $P$. periphylla biomass at night was approximately half that of copepods, which did not migrate vertically. The DOM provided by copepods and their sloppy feeding (Møller et al. 2003) may be of better quality than DOM released from jellyfish. Similarly, the bacterial community analyses showed no diurnal signal in composition (data not shown). Although the bacterial community grew slowly (doubling time of up to $10 \mathrm{~d}$; abundance divided by daily production; data not shown) single bacterial species may grow $>5$ times faster than the average 
community (Pinhassi et al. 1999). Hence, changes in bacterial community composition in response to substrate provided by the migrating $P$. periphylla population were theoretically possible on a $24 \mathrm{~h}$ scale.

\section{CONCLUSION}

Here, we examined microbial activity and community composition in a natural marine system where jellyfish dominates biomass. At depth the jellyfish seemed to stimulate microbial activity, while this could not be demonstrated near the surface. Generally, jellyfish, TOC and bacterial activity measures all had minima at mid-depth and increasing values towards the bottom. The coinciding vertical patterns of jellyfish biomass and TOC at depth indicate a possible leakage of organic matter from jellyfish tissue or feeding activity. The increase in TOC levels at depth was in turn correlated with increased bacterial activities. Several bacterial phylotypes were specifically found at the depths with highest jellyfish biomass, possibly reflecting bacterial functional adaptations to the local substrate regime. In an accompanying paper we show that Periphylla periphylla may indeed both stimulate and retard bacterial growth suggesting a release of both substrate and inhibitory compounds, as well as a possible impact on bacterial community composition (Titelman et al. 2006). Thus, P. periphylla has the potential to affect bacteria, but a causal link between the depthspecific bacterial phylotypes and the jellyfish $P$. periphylla cannot be unambiguously established from these field data. Nevertheless, we suggest that jellyfish proliferations may directly and indirectly affect trophic levels down to microbes in the pelagic foodweb.

Acknowledgements. We thank P. Griekspoor for technical assistance in sequencing analyses, C. Legrand for advice on ciliate and phytoplankton examinations, T. Nilsen, J. E. Skjæraasen and C. Legrand for discussions on statistics, and the crew of RV 'Haakon Mosby' for help with sampling. Nutrient and TOC were analysed at Umeå Marine Science Centre. T. Sørnes kindly commented on an earlier draft. We also thank the reviewers for constructive comments. This work formed part of the EUROGEL project funded by the European Commission (EVK3-CT-2002-00074; U.B., J.T.). Additional financial support was given by FORMAS (2004-2539; L.R., J.T.).

\section{LITERATURE CITED}

Acinas SG, Klepac-Ceraj V, Hunt DE, Pharino C, Ceraj I, Distel DL, Polz MF (2004) Fine-scale phylogenetic architecture of a complex bacterial community. Nature 430:551-554

Aksnes DL, Nejstgaard J, Sædberg E, Sørnes T (2004) Optical control of fish and zooplankton populations. Limnol Oceanogr 49:233-238

Altschul SF, Gish W, Miller W, Myers EW, Lipman DJ (1990) Basic local alignment search tool. J Mol Biol 215:403-410
Bano N, Hollibaugh JT (2002) Phylogenetic composition of bacterioplankton assemblages from the Arctic Ocean. Appl Environ Microbiol 68:505-518

Berggreen U, Hansen B, Kiørboe T (1988) Food size spectra, ingestion and growth of the copepod Acartia tonsa during development: implications for determination of copepod production. Mar Biol 99:341-352

Bjørnsen PK (1988) Phytoplankton exudation of organic matter: Why do healthy cells do it? Limnol Oceanogr 33:151-154

Boström KH, Simu K, Hagström A, Riemann L (2004) Optimization of DNA extraction for quantitative marine bacterioplankton community analysis. Limnol Oceanogr Methods 2:365-373

Carlson CA, Ducklow HW, Michaels AF (1994) Annual flux of dissolved organic carbon from the euphotic zone in the northwestern Sargasso Sea. Nature 371:405-408

Castle D, Kirchman DL (2004) Composition of estuarine bacterial communities assessed by denaturing gradient gel electrophoresis and fluorescence in situ hybridization. Limnol Oceanogr Methods 2:303-314

Cole JR, Chai B, Marsh TL, Farris RJ and 7 others (2003) The Ribosomal Database Project (RDP-II): previewing a new autoaligner that allows regular updates and the new prokaryotic taxonomy. Nucleic Acids Res 31(1):442-443

Cottrell MT, Kirchman DL (2000) Natural assemblages of marine Proteobacteria and members of the Cytophaga-Flavobacter cluster consuming low- and high-molecular-weight dissolved organic matter. Appl Environ Microbiol 66:1692-1697

DeLong EF, Franks DG, Alldredge AL (1993) Phylogenetic diversity of aggregate-attached vs. free-living marine bacterial assemblages. Limnol Oceanogr 38:924-934

Eiane K, Aksnes DL, Bagøien E, Kaartvedt S (1999) Fish or jellies - a question of visibility? Limnol Oceanogr 44: 1352-1357

Fandino LB, Riemann L, Steward GF, Long RA, Azam F (2001) Variations in bacterial community structure during a dinoflagellate bloom analyzed by DGGE and 16S rDNA sequencing. Aquat Microb Ecol 23:119-130

Fuhrman JA, Azam F (1982) Thymidine incorporation as a measure of heterotrophic bacterioplankton production in marine surface waters: evaluation and field results. Mar Biol 66:109-120

Fuhrman JA, McCallum K, Davis AA (1993) Phylogenetic diversity of subsurface marine microbial communities from the Atlantic and Pacific Oceans. Appl Environ Microbiol 59: $1294-1302$

Gasol JM, del Giorgio PA (2000) Using flow cytometry for counting natural planktonic bacteria and understanding the structure of planktonic bacterial communities. Sci Mar 64:197-224

Gonzalez JM, Simó R, Massana R, Covert JS, Casamayor EO, Pedrós-Alio C, Moran MA (2000) Bacterial community structure associated with a dimethylsulfoniopropionateproducing North Atlantic algal bloom. Appl Environ Microbiol 66:4237-4246

Grasshoff K, Ehrhardt M, Kremling K (1983) Methods of seawater analysis. Verlag Chemie, Weinheim

Hansson LJ, Norrman B (1995) Release of dissolved organic carbon (DOC) by the scyphozoan jellyfish Aurelia aurita and its potential influence on the production of planktonic bacteria. Mar Biol 121:527-532

Hoppe HG, Ducklow H, Karrasch B (1993) Evidence for dependency of bacterial growth on enzymatic hydrolysis of particulate organic matter in the mesopelagic ocean. Mar Ecol Prog Ser 93:277-283

Janson S (2004) Molecular evidence that plastids in the toxinproducing dinoflagellate genus Dinophysis originate from 
the free-living cryptophyte Teleaulax amphioxeia. Environ Microbiol 6:1102-1106

Kirchman DL (2002) The ecology of Cytophaga-Flavobacteria in aquatic environments. FEMS Microbiol Ecol 1317:1-10

Kisand V, Wikner J (2003) Combining culture-dependent and independent methodologies for estimation of richness of estuarine bacterioplankton consuming riverine dissolved organic matter. Appl Environ Microbiol 69:3607-3616

Lee SH, Fuhrman JA (1987) Relationships between biovolume and biomass of naturally derived marine bacterioplankton. Appl Environ Microbiol 53:1298-1303

Lynam CP, Hay SJ, Brierley AS (2004) Interannual variability in abundance of North Sea jellyfish and links to the North Atlantic Oscillation. Limnol Oceanogr 49:637-643

Martinez J, Smith DC, Steward GF, Azam F (1996) Variability in ectohydrolytic enzyme activities of pelagic marine bacteria and its significance for substrate processing in the sea. Aquat Microb Ecol 10:223-230

Menden-Deuer S, Lessard EJ (2000) Carbon to volume relationships for dinoflagellates, diatoms, and other protist plankton. Limnol Oceanogr 45:569-579

Mills CE (2001) Jellyfish blooms: Are populations increasing globally in response to changing ocean conditions? Hydrobiol 451:55-68

Møller EF, Thor P, Nielsen TG (2003) Production of DOC by Calanus finmarchicus, C. glacialis, and C. hyperboreus through sloppy feeding and leakage from fecal pellets. Mar Ecol Prog Ser 262:185-191

Murray AE, Preston CM, Massana R, Taylor LT, Blakis A, Wu K, DeLong EF (1998) Seasonal and spatial variability of bacterial and archaeal assemblages in the coastal waters near Anvers Island, Antarctica. Appl Environ Microbiol 64:2585-2595

Muyzer G, De Waal EC, Uitterlinden AG (1993) Profiling of complex microbial populations by denaturing gradient gel electrophoresis analysis of polymerase chain reactionamplified genes coding for 16S rRNA. Appl Environ Microbiol 59:695-700

Muyzer G, Brinkhoff T, Nübel U, Santegoeds CM, Schäfer H, Wawer C (1998) Denaturing gradient gel electrophoresis (DGGE) in microbial ecology. In: Akkermans ADL, van Elsas JD, De Bruin FJ (eds) Molecular microbial ecology manual. Kluwer Academic Publishers, London, Section 344:1-27

Nemazie DA, Purcell JE, Glibert PM (1993) Ammonium excretion by gelatinous zooplankton and their contribution to the ammonium requirements of microplankton in Chesapeake Bay. Mar Biol 116:451-458

Noble RT, Fuhrman JA (1998) Use of SYBR Green I for rapid epifluorescence counts of marine viruses and bacteria. Aquat Microb Ecol 14:113-118

Olesen NJ (1995) Clearance potential of jellyfish Aurelia aurita, and predation impact on zooplankton in a shallow cove. Mar Ecol Prog Ser 124:63-72

Pinhassi J, Azam F, Hemphälä J, Long RA, Martinez J, Zweifel UL, Hagström ^̊ (1999) Coupling between bacterioplankton species composition, population dynamics, and organic matter degradation. Aquat Microb Ecol 17:13-26

Priddle J, Whitehouse MJ, Ward P, Shreeve RS and 5 others (2003) Biogeochemistry of a Southern Ocean plankton ecosystem: using natural variability in community composition to study the role of metazooplankton in carbon and nitrogen cycles. J Geophys Res 108 (C4):no. 8082

Purcell JE, Arai MN (2001) Interactions of pelagic cnidarians and ctenophores with fish: a review. Hydrobiol 451:27-44

Rey-Rassat C, Bonnet D, Irigoien X, Harris R, Head R, Carlotti F (2004) Is weight an important parameter when measuring copepod growth? J Exp Mar Biol Ecol 313:19-27

Riemann L, Middelboe M (2002) Stability of bacterial and viral community compositions in Danish coastal waters as depicted by DNA fingerprinting techniques. Aquat Microb Ecol 27:219-232

Riemann L, Winding A (2001) Community dynamics of free-living and particle-associated bacterial assemblages during a freshwater phytoplankton bloom. Microb Ecol 42:274-285

Riemann B, Bjørnsen PK, Newell S, Fallon R (1987) Calculation of cell production of coastal marine bacteria based on measured incorporation of $\left({ }^{3} \mathrm{H}\right)$ thymidine. Limnol Oceanogr 32: 471-476

Riemann L, Steward GF, Fandino LB, Campbell L, Landry MR, Azam F (1999) Bacterial community composition during two consecutive NE Monsoon periods in the Arabian Sea studied by denaturing gradient gel electrophoresis (DGGE) of rRNA genes. Deep-Sea Res II 46:1791-1811

Riemann L, Steward GF, Azam F (2000) Dynamics of bacterial community composition and activity during a mesocosm diatom bloom. Appl Environ Microbiol 66:578-587

Sabatini M, Kiørboe T (1994) Egg production, growth and development of the cyclopoid copepod Oithona similis. J Plankton Res 16:1329-1351

Schneider G (1989) The common jellyfish, Aurelia aurita: standing stock, excretion and nutrient regeneration in the Kiel Bight, Western Baltic. Mar Biol 100:507-514

Schäfer H, Abbas B, Witte H, Muyzer G (2002) Genetic diversity of 'satellite' bacteria present in cultures of marine diatoms. FEMS Microbiol Ecol 42:25-35

Selje N, Simon M, Brinkhoff T (2004) A newly discovered Roseobacter cluster in temperate and polar oceans. Nature 427:445-448

Šimek K, Kojecká P, Nedoma J, Hartman P, Vrba J, Dolan J (1999) Shifts in bacterial community composition associated with different microzooplankton size fractions in a eutrophic reservoir. Limnol Oceanogr 44:1634-1644

Sørnes TA (2005) Visual or tactile zooplanktovores - structuring effects of the underwater visual environment. $\mathrm{PhD}$ thesis, University of Bergen, Bergen

Stibor H, Vadstein O, Diehl S, Gelzleichter A and 10 others (2004) Copepods act as a switch between alternative trophic cascades in marine pelagic food webs. Ecol Lett 7:321-328

Takishita K, Kazuhiko K, Maruyama T, Ogata T (2005) Molecular evidence for plastid robbery (kleptoplastidy) in Dinophysis, a dinoflagellate causing diarrhetic shellfish poisoning. Protist 153:293-302

Titelman J, Riemann L, Sørnes TA, Nilsen T, Griekspoor P, Båmstedt U (2006) Turnover of dead jellyfish: stimulation and retardation of microbial activity. Mar Ecol Prog Ser 325:43-58

Wen K, Ortmann AC, Suttle CA (2004) Accurate estimation of viral abundance by epifluorescence microscopy. Appl Environ Microbiol 70:3862-3867

Wintzingerode FV, Göbel UB, Stackebrandt E (1997) Determination of microbial diversity in environmental samples: pitfalls of PCR-based rRNA analysis. FEMS Microb Rev 21: 213-229

Wright TD, Vergin KL, Boyd PW, Giovannoni SJ (1997) A novel delta-subdivision proteobacterial lineage from the lower ocean surface layer. Appl Environ Microbiol 63:1441-1448

Youngbluth MJ, Båmstedt U (2001) Distribution, abundance, behavior and metabolism of Periphylla periphylla, a mesopelagic coronate medusa in a Norwegian fjord. Hydrobiol 451:321-333

Zubkov MV, Fuchs BM, Archer SD, Kiene RP, Amann R, Burkill PH (2002) Rapid turnover of dissolved DMS and DMSP by defined bacterioplankton communities in the stratified euphotic zone of the North Sea. Deep-Sea Res II 49: $3017-3038$

Submitted: May 4, 2005; Accepted: March 31, 2006

Proofs received from author(s): October 24, 2006 